\title{
KONTRIBUSI KEGIATAN PRODUKTIF PEREMPUAN TANI TERHADAP PENDAPATAN RUMAHTANGGA PETANI DI KECAMATAN PEMENANG KABUPATEN LOMBOK UTARA
}

\section{THE CONTIBUTION OF PRODUKTIVE ACTIVITIES OF WOMEN FARMERS TO THE INCOME OF FARMER HOUSEHOLDS IN PEMENANG DISTRICTS OF NORTH LOMBOK REGENCY}

\author{
Afriantini, Sri Supartiningsih, dan Anwar \\ Program Studi Agribisnis Fakultas Pertanian Universitas Mataram
}

\begin{abstract}
ABSTRAK
Keragaan kegiatan ekonomi produktif perempuan tani dapat memberikan kontribusi yang sangat berarti bagi rumahtangga petani, berdasarkan alasan tersebut penelitian ini bertujuab : (1) Untuk menganalisis pendapatan perempuan tani dari berbagai jenis kegiatan produktif, (2) Untuk menganalisis kontribusi pendapatan perempuan tani terhadap pendapatan rumah tangga petani di Kecamatan Pemenang Kabupaten Lombok Utara.

Metode yang digunakan dalam penelitian ini adalah metode deskriptif dengan unit analisis adalah rumah tangga petani. Daerah penelitian ini ditentukan secara purposive sampling, yaitu: Desa Pemenang Barat dan Desa Pemenang Timur. Penentuan jumlah responden ditetapkan dengan metode quota sampling

Hasil penelitian menunjukkan bahwa: (1) Kegiatan produktif perempuan tani meliputi: kegiatan pada usahatani sendiri sebanyak 20 orang $(47,5 \%)$, dengan ratarata pendapatan per bulan Rp. 169.465; berdagang sebanyak 11 orang (27,5\%) dengan rata-rata pendapatan Rp. 3.609.500; pengolahan VCO sebanyak 9 orang $(22,5 \%)$, rata-rata pendapatannya $\mathrm{Rp} .803 .121$; dan jasa 3 orang $(7,5 \%)$, dengan ratarata pedapatan per bulan Rp. 1.600.000. (2) Kontribusi pendapatan perempuan tani terhadap pendapatan rumah tangga petani sebesar 52,85\%, kontribusi terbesar bersumber dari kegiatan berdagang.
\end{abstract}

Kata Kunci: Kegiatan Produktif, Kontribusi Pendapatan Perempuan Tani 


\section{ABSTRACT}

Performance of productive economic activities of women farmers can contribute significant for farm household. For that reason, the object of the study : (1) analize the income of women farmers from various types of productive activities, (2) analize the contribution of women farmers to the income of farmer households in Pemenang District, North Lombok Regency.

The study used a descriptive method with an analysis unit that is a farmer household. The research area is determined by purposive sampling, is Pemenang Barat Village and Pemenang Timur Village. Determination of the number of respondent is determined by quota sampling method.

The results of the study indicate as below:(1) The productive activity of women farmers are works in the own farming are 20 women farm (47,5\%), get average of income Rp.169.465 per month; in trading activity are 11 women (27,5\%), get average of income Rp.3.609.500 per month; in the vco agroindustri are 9 women (22,5\%), get average of income Rp.803.121 per month and in the service actiities are 3 women and get income Rp.1.600.000 per month.(2) The contribution of female farmer income to farm household income is $52,85 \%$ and the largest contribution comes from trading activities

Key Words: productive activity, income contribution of female farmer

\section{PENDAHULUAN}

Perempuan tani merupakan istri petani yang ikut berperan dalam mencari nafkah untuk keluarganya. Sumbangan kaum perempuan tani khususnya dalam menambah penghasilan keluarga dampaknya akan cukup besar (Sulistiyaningsih, 2000). Dari studi awal diperoleh gambaran bahwa peran wanita dalam mencari nafkah di Kabupaten Lombok Utara khususnya Kecamatan Pemenangadalah suatu hal yang lumrah dilakukan. Fakta ini menunjukkan bahwa terbukanya peluang kerja bagi para wanita, wanita bisa bekerja dalam berbagai kegiatan produktif, dalam berbagai sektor seperti sektor usahatani sendiri, luar usahatani sendiri, dan non usahatani, mengingat wanita tani memiliki peran ganda dalam halpekerjaan rumahtangga dan menghasilkan pendapatan.

Peran wanita dalam mencari nafkah di Kabupaten Lombok Utara khususnya Kecamatan Pemenang meliputi berbagai pekerjaan produktif seperti membuka usaha berdagang di kios-kios kecil, berdagang dipasar, membantu suami bekerja di sawah maupun menjadi buruh tani, pengolahan agroindustri seperti membuat sate ikan, membuat kerupuk dari ubi yang biasa disebut opak-opak oleh masyarakat Terlibatnya wanita dalam mencari nafkah untuk keluarganya diharapkan akan membantu dalam 
usaha meningkatkan pendapatan keluarganya sehingga tercapai kesejahteraan yang diinginkan.

Oleh karena itu telah dilakukan penelitian tantang "Kontribusi Kegiatan Produktif Perempuan Tani Terhadap Pendapatan Rumahtangga Petani di Kecamatan Pemenang Kabupaten Lombok Utara".

Penelitian ini bertujuan untuk mengetahui: (1) Untuk menganalisis pendapatan perempuan tani dari berbagai jenis kegiatan produktif, (2) Untuk menganalisis kontribusi pendapatan perempuan tani terhadap pendapatan rumah tangga petani di Kecamatan Pemenang Kabupaten Lombok Utara.

\section{METODE PENELITIAN}

Penelitian ini menggunakan metode deskriptif. Teknik pengumpulan data menggunakan teknik survei. Unit analisis dalam penelitian ini adalah rumah tangga petani dimana perempuan tani atau ibu rumah tangga (istri) ikut serta dalam mencari nafkah untuk meningkatkan pendapatan keluarganya. Jenis data dalam penelitian ini adalah data kuantitatif dan data kualitatif, sedangkan sumber data dalam penelitian ini yaitu: data primer dan data sekunder.

Penentuan daerah penelitian dilakukan di Kecamatan Pemenang Kabupaten Lombok Utara yang terdiridari empat desa yaitu, Desa Malaka, Desa Pemenang Barat, Desa Pemenang Timur, dan Desa Gili Indah. Dari empat desa tersebut ditentukan dua desa yaitu Desa Pemenang Barat dan Desa Pemenang Timuratas petimbangan bahwa desa tersebutterdapat daerah lahan pertanian dan istri petani yang ikut mencari nafkah lebih banyak dari desa yang lain.

Responden dalam penelitian ini adalah anggota rumah tangga petani (Ibu, Ayah, Anak) yang bekerja. Jumlah responden ditentukan secara quota sampling, yaitu ibu rumahtangga petani yang melakukan kegiatan produktif dengan jumlah responden yang diambil sebanyak masing-masing 20 orang per desa yaitu Desa Pemenang Barat dan Desa Pemenang Timur. Jadi total responden sebanyak 40 orang. Penetuan responden tersebut dilakukan dengan accidental sampling. 


\section{HASIL DAN PEMBAHASAN}

\section{Karakteristik Responden}

Karakteristik responden perempuan tani dari penelitian ini disajikan pada Tabel 1 berikut.

Tabel 1. KarakteristikRespondenPerempuan Tani di Kecamatan Pemenang Kabupaten Lombok Utara

\begin{tabular}{|c|c|c|c|c|c|c|}
\hline \multirow[b]{2}{*}{ No } & \multirow[b]{2}{*}{ Uraian } & \multirow{2}{*}{$\begin{array}{c}\text { Perempuan } \\
\text { Tani }\end{array}$} & \multicolumn{4}{|c|}{ Jenis Usaha } \\
\hline & & & $\begin{array}{c}\text { Usahatani } \\
\text { sendiri }\end{array}$ & Pedagang & Industri & Jasa \\
\hline 1 & Jumlah Responden(n) & 40 & 19 & 11 & 9 & 3 \\
\hline 2 & $\begin{array}{l}\text { Umur Responden; } \\
\text { - Rata-rata (Tahun) } \\
\text { - Kisaran (Tahun) }\end{array}$ & $\begin{array}{c}43 \\
25-80\end{array}$ & $\begin{array}{c}48 \\
40-60\end{array}$ & $\begin{array}{c}44 \\
30-80\end{array}$ & $\begin{array}{c}32 \\
25-41\end{array}$ & $\begin{array}{c}33 \\
25-38\end{array}$ \\
\hline 3 & $\begin{array}{l}\text { Tingkat Pendidikan; } \\
\text { - Tidak Sekolah } \\
\text { - Tamat SD } \\
\text { - Tamat SMP } \\
\text { - Tamat SMA } \\
\text { - Perguruan Tinggi } \\
\end{array}$ & $\begin{array}{c}13(32,5 \%) \\
13(32,5 \%) \\
9(22,5 \%) \\
3(7,5 \%) \\
2(5 \%) \\
\end{array}$ & $\begin{array}{l}9 \\
5 \\
4 \\
1 \\
-\end{array}$ & $\begin{array}{l}4 \\
5 \\
1 \\
1 \\
-\end{array}$ & $\begin{array}{l}- \\
3 \\
3 \\
1 \\
2\end{array}$ & $\begin{array}{l}- \\
- \\
1 \\
- \\
2\end{array}$ \\
\hline 4 & $\begin{array}{l}\text { Tanggungan Keluarga; } \\
\text { - Rata-rata (Orang) } \\
\text { - Kisaran (Orang) }\end{array}$ & $\begin{array}{c}4 \\
1-8\end{array}$ & $\begin{array}{c}4 \\
2-6\end{array}$ & $\begin{array}{c}4 \\
2-7\end{array}$ & $\begin{array}{c}4 \\
2-8\end{array}$ & $\begin{array}{c}2 \\
3-6\end{array}$ \\
\hline 5 & $\begin{array}{l}\text { Pengalaman Usaha; } \\
\text { - Rata-rata (Tahun) } \\
\text { - Kisaran (Tahun) }\end{array}$ & $\begin{array}{c}14 \\
1-50\end{array}$ & $\begin{array}{c}22 \\
5-40\end{array}$ & $\begin{array}{c}13 \\
1-50\end{array}$ & $\begin{array}{c}1 \\
0-1\end{array}$ & $\begin{array}{c}2 \\
1-3\end{array}$ \\
\hline 6 & $\begin{array}{l}\text { Luas Lahan Garapan; } \\
\text { - Rata-rata (Ha) } \\
\text { - Kisaran }\end{array}$ & $\begin{array}{c}0,25 \\
0,08-0,45\end{array}$ & $\begin{array}{c}0,25 \\
0,08-0,45\end{array}$ & - & - & - \\
\hline
\end{tabular}

Sumber: Data Primer Diolah 2018

Hampir seluruh responden berada pada kisaran umur produktif dengan ratarata uimur 43 tahun, dengan kisaran umur 25 - 80 tahun. Pendidikan responden terbanyak berada pada level tidak sekolah dan tamat SD, meskipun demikian terdapat responden dengan tingkat pendidikan perguruan tinggi yaitu sebesar 5 persen, dengan kegiatan produktif mengolah VCO dan jasa (guru dan admin perusahaan). Rata-rata jumlah tanggungan 4 orang dengan kisaran 1-8 orang. Sedangkan Pengalaman responden pada kegiatan produktif rata-rat 14 tahun dengan kisaran 150 tahun, pengalaman yang terendah adalah pada kegiatan mengolah VCO yaitu 1 tahun.

\section{Sumber-Sumber Pendapatan Ibu Rumah Tangga}

Pendapatan responden ibu rumah tangga di daerah penelitian diperoleh dari berbagai usaha produktif yang dijalankan ibu rumah tangga responden seperti 
perdagangan, industri minyak VCO dan usaha jasa. Dari 40 responden yang sudah ditetapkan, diperoleh 19 orang $(47,5 \%)$ responden yang melakukan usahatani sendiri,11 orang $(27,5 \%)$ responden yang melakukan kegiatan usaha perdagangan, 9 orang $(22,5 \%)$ responden yang melakukan kegiatan usaha industri minyak VCO dan 3 orang $(7,5 \%)$ responden yang melakukan kegiatan usaha jasa.

Adapun ibu rumah tangga responden yang menjalankan kegiatan usaha ganda sebanyak 5 orang yakni 2 orang ibu rumah tangga yang menjalankan kegiatan usaha jasa dan juga bekerja sebagai pembuat minyak VCO dan 3 orang ibu rumah tangga responden menjalankan usaha perdagangan dan juga bekerja sebagai petani.

\section{Pendapatan Perempuan Tani dari Kegiatan Berdagang}

Pendapatan dari usaha tani sendiri seringkali belum dapat memenuhi kebutuahan pokok keluarga, karena pendapatan yang diperoleh dari kegiatan usaha tani sendiri hanya diperoleh setiap musim sedangkan kebutuhan hidup setiap hari harus tetap terpenuhi. Hal ini mendorong para ibu rumah tangga di Desa Pemenang Barat dan Desa Pemenang Timur melakukan kegiatan usaha yang dapat menghasilkan mendapatkan. Salah satu usaha yang dilakukan adalah usaha perdagangan.

Dari 40 responden yang ditetapkan, diperoleh 11 orang $(27,5 \%)$ responden yang melakukan kegiatan usaha perdagangan, namun jenis barang yang dijual antara responden satu dengan responden yang lainnya berbeda-beda. Jenis barang yang dijual antara pedagang responden yang satu dengan pedagang responden yang lainnya adalah sembako, bumbu dapur, pakaian dan tembakau

Pendapatan yang dimaksud dalam penelitian ini adalah pendapatan yang diterima pedagang setelah dikurangi dengan seluruh biaya yang dikeluarkan, yang disajikan pada Tabel 2 berikut.

Tabel 2. Rata-rata Pendapatan Perempuan Tani dari Kegiatan berdagang

\begin{tabular}{|c|l|c|c|}
\hline No & \multicolumn{1}{|c|}{ Sumber Pendapatan } & $\begin{array}{c}\text { Jumlah } \\
\text { (Orang) }\end{array}$ & $\begin{array}{c}\text { Pendapatan } \\
\text { (Rp/bulan) }\end{array}$ \\
\hline 1 & Pedagang sembako & 6 & 2.830 .000 \\
2 & Pedagang Bumbu dapur & 3 & 1.643 .000 \\
3 & Pedagang Pakaian & 1 & 1.200 .000 \\
4 & Pedagang Tembakau & 1 & 7.900 .000 \\
\hline \multicolumn{2}{|c|}{ Rata-rata } & 3.054 .909 \\
\hline
\end{tabular}

Sunber: Data Primer Diolah

Pendapatan terbesar diperoleh dari berdagang Tembakau, namun yang memiliki akses untuk berdagang tembakau hanya 1 orang, perempuan tani lebih banyak yang melakukan kegiatan berdagang sembako.

\section{Pendapatan Perempuan Tani dari Kegiatan Pengolahan VCO (Agroindustri RT)}

Agroindustri adalah kegiatan poduktif lain yang dilakukan oleh ibu rumah tangga di kabupaten Lombok Utara. Jenis agroindutri yang ditekuni penduduk pun berbeda-beda, diantaranya pengolahan makanan seperti sate ikan laut, kerupuk ubi atau opak-opak serta indutri pengolahan kelapa menjadi minyak yang biasa dikenal dengan sebutan minyak VCO (Virgin Coconut Oil) atau minyak kelapa murni tanpa proses pematangan. Pengolah minyak VCO ini baru dimulai pada tahun 2016 lalu 
yang digagas oleh Kelompok Wanita Tani Ifrat yang berlokasi di Dusun Montong Bae Desa Pemenang Barat, setelah mendapatkan pelatihan dari pihak luar.

Pada penelitian ini diperoleh 9 orang $(22.5 \%)$ responden wanita tani yang melakukan kegiatan industri pengolahan minyak VCO. Sebagian sebagai usaha sampingan dan sebagian lainnya sebagai usaha utama.

Bahan baku yang digunakan dalam menjalankan industri minyak VCO ini yaitu kelapa yang bersifat tidak terlalu kering dan juga tidak terlalu basah. Dalam memperoleh bahan baku ibu rumah tangga responden membelinya pada orang-orang/ tetangga yang memiliki kebun kelapa. Agar memperoleh kelapa yang diinginkan dan bisa langsung diolah.

Produksi yang dimaksud dalam penelitian ini adalah hasil pengolahan kelapa berupa minyak VCO. Rata-rata nilai produksi minyak VCO sebesar Rp. 3.289.000 per bulan, dan rata-rata produksi sebanyak 50,6 liter per bulan dengan harga Rp 65.000 per liter. Besarnya rata-rata pendapatan yang diterima perempuan tani selama satu bulan dapat dilihat pada Tabel 3.

Tabel 3. Rata-Rata Pendapatan Perempuan Tani dari Pengolahan VCO

\begin{tabular}{|c|l|r|}
\hline No & \multicolumn{1}{|c|}{ Uraian } & \multicolumn{1}{|c|}{ Nilai } \\
\hline 1 & Jumlah produksi (liter/bln) & 25 \\
2 & Harga (Rp/liter) & 65.000 \\
3 & Nilai Produksi (Rp/bln) & 1.625 .000 \\
4 & Biaya Produksi (Rp/bln) & 821.879 \\
5 & Pendapatan (Rp/bln) & 803.121 \\
\hline
\end{tabular}

Sumber: Data Primer Diolah

Dari Tabel 3 dapat diketahui bahwa pendapatan produsen minyak VCO diperoleh dari total nilai produksi dikurangi total biaya produksi yang dikeluarkan dalam satu bulan, sehingga diperoleh rata-rata pendapatan sebesar Rp 803.121 per bulan.

\section{Pendapatan Perempuan Tani dari Jasa}

Terdapat 3 orang $(7,5 \%)$ responden perempuan tani yang melakukan kegiatan usaha jasa. Kegiatan usaha jasa yang dijalankan berbeda antara responden satu dengan responden yang lainnya. Terdapat responden yang bekerja sebagai Guru tetap, karyawan hotel dan admin perusahaan.

Upah yang diterima pada masing-masing kegiatan usaha jasa tentunya berbeda-beda sesuai dengan jenis kegiatan jasa yang dilakukan, dengan rata-rata sebesar Rp. 1.600.000 per bulan

Rata-rata upah yang diterima ibu rumah tangga responden dalam menjalankan kegiatan usaha jasa dapat dilihat pada Tabel 4.

Tabel 4. Rata-rata Upah yang Diterima Perempuan Tani dari Jasa

\begin{tabular}{|c|l|c|c|}
\hline No & \multicolumn{1}{|c|}{ Uraian } & Jumlah (Orang) & Upah (Rp/thn) \\
\hline 1 & Guru & 1 & 1.500 .000 \\
2 & Kariawan Hotel & 1 & 1.500 .000 \\
3 & Admin Perusahaan & 1 & 1.800 .000 \\
\hline
\end{tabular}




\begin{tabular}{|c|c|}
\hline Rata-rata Upah (Rp/thn) & 1.600 .000 \\
\hline
\end{tabular}

Sumber: Data Primer Diolah

\section{Pendapatan Rumah Tangga dari Usahatani Sendiri}

Produksi yang dimaksud dalam penelitian ini adalah hasil panen yang diperoleh petani responden dari kegiatan usahatani sendiri. Jumlah produksi yang diperoleh tergantung dari luas lahan tanam, kualitas bibit tanam, perawatan tanaman, kesuburan tanah dan ketersediaan air serta iklim yang mendukung atau tidak. Jenis tanam yang diusahakan oleh petani responden berbeda-beda antara lain, Padi, Jagung, Cabai, Kacang Tanah, Kacang Panjang, Kangkung dan Tembakau. Namun tanaman yang paling banyak ditanam oleh petani responden adalah Padi dan Cabai. Untuk mengetahui rata-rata nilai produksi pada setiap tanaman yang diusahakan tersebut dapat dilihat pada Tabel 5.

Tabel 5. Rata-rata Nilai Produksi pada Setiap Tanaman yang Diusahakan oleh Petani Responden

\begin{tabular}{|c|l|c|r|}
\hline No & \multicolumn{1}{|c|}{ Jenis Tanaman } & $\begin{array}{c}\text { Jumlah Produksi } \\
\text { (per thn) }\end{array}$ & $\begin{array}{r}\text { Nilai Produksi (Rp/ } \\
\text { thn) }\end{array}$ \\
\hline 1 & Padi & $10 \mathrm{KW}$ & 3.620 .875 \\
2 & Kacang Tanah & $1,47 \mathrm{Kw}$ & 1.174 .750 \\
3 & Jagung & $0,29 \mathrm{Kw}$ & 170.250 \\
4 & Kacang Panjang & $0,19 \mathrm{Kw}$ & 78.750 \\
5 & Cabai & $0,85 \mathrm{Kw}$ & 915.500 \\
6 & Kangkung & $5 \mathrm{ikat}$ & 10.000 \\
7 & Tembakau & $2,23 \mathrm{Kw}$ & 1.112 .500 \\
\hline & Nilai Produksi & & 7.082 .625 \\
\hline
\end{tabular}

Sumber: Data Primer Diolah

Dari Tabel 5 dapat diketahui bahwa rata-tata nilai produksi padi sebesar Rp 3.620.875 per tahun dengan jumlah produksi $10 \mathrm{Kw}$. Harga per Kw padi basah adalah Rp 350.000 sedangkan padi kering Rp 400.000. petani responden umumnya menjual hasil produksi padi dalam keadaan basah. Rata-rata nilai produksi kacang tanah yang diterima petani responden adalah sebesar Rp 1.174 .750 per tahun dengan jumlah 1,47 Kw. petani menjual produksi kacang tanah dengan kisaran harga antara Rp 4.500 - Rp 28.000 per Kg. Rata-rata nilai produksi jagung yang diterima petani responden adalah sebesar Rp 170.250 per tahun dengan jumlah 0,29 Kw. Petani menjual produksi jagung dengan kisaran harga antara Rp 4000-Rp 10.000 per Kg. Rata-rata nilai produksi kacang panjang yang diterima petani responden adalah sebesar Rp 78.750 per tahun dengan jumlah 0,19 Kw. Petani menjual produksi kacang panjang dengan kisaran harga antara $\mathrm{Rp} 4000-\mathrm{Rp} 5000$ per $\mathrm{Kg}$. Rata-rata nilai produksi cabai yang diterima petani responden adalah sebesar Rp 915.500 per tahun dengan jumlah $0,85 \mathrm{Kw}$. Petani menjual produksi cabai dengan kisaran harga antara Rp 5000-Rp 30.000 per Kg. Rata-rata nilai produksi kangkung yang diterima petani responden adalah sebesar Rp 10.000 per tahun dengan jumlah 5 ikat. Petani menjual produksi kangkung dengan kisaran harga antara Rp 2000 per ikat. Rata-rata nilai produksi tembakau yang diterima petani responden adalah sebesar Rp 1.112 .500 per tahun dengan jumlah 2,23 Kw. Petani menjual produksi tembakau dengan kisaran harga antara Rp 500.000 per ball. 
Berdasarkan rata-rata nilai produksi yang diterima petani tesponden seperti yang terjadi pada Tabel 5 dapat diketahui bahwa nilai produksi pada usahatani sendiri dalam satu tahun adalah sebesar Rp 7.082.625 per tahun.

Pendapatan dari usahatani dalam penelitian ini dihitung dengan mengurangi nilai produksi dengan seluruh biaya yang dikeluarkan pada usahatani tersebut. Berikut untuk mengetahui rata-rata pendapatan yang diperoleh rumahtangga petani dalam usahatani sendiri dapat dilihat pada Tabel 6 .

Tabel 6. Rata-rata Pendapatan yang Diperoleh Rumahtangga Petani pada Kegiatan Usahatani Sendiri dalam Satu Tahun

\begin{tabular}{|c|l|c|}
\hline No & \multicolumn{1}{|c|}{ Uraian } & Jumlah (Rp/tahun) \\
\hline 1 & Nilai Produksi & 7.082 .625 \\
2 & Biaya Produski & 4.236 .313 \\
3 & Pendapatan Rumahtangga & 2.846 .313 \\
\hline
\end{tabular}

Sumber: Data Primer Diolah

Dari Tabel 6 Dapat diketahui bahwa rata-rata pendapatan rumahtangga petani pada kegiatan usahatani sendiri yaitu $\mathrm{Rp} 2.846 .313$ per tahun. Untuk pendapatan perempuan tani pada usahatani sendiri diperoleh dengan cara memperhitungkan jam kerja perempuan tani yang ikut bekerja bersama suami dikalikan pendapatan usahatani sendiri lalu dibagi dua sedangkan yang janda atau suami tidak ikut berkerja pada usahatani sendiri tetap menjadi satu perhitungan, sehingga diperoleh pendapatan perempuan tani pada usahatani sendiri sebesar Rp 1.016.788 per tahun.

\section{Pendapatan Anggota Rumah Tangga Lainnya dari Luar Usahatani Sendiri dan Luar Usahatani}

Pendapatan ini berasal dari semua anggota keluarga selain ibu (bapak dan anak) yang melakukan kegiatan usaha diluar usahatani sendiri dan luar usahatani seperti buruh, sopir, dagang, kariawan toko, guru honorer, pengebor sumur dan wiraswasta, dari Tabel 7 dapat diketahui bahwa rata-rata pendapatan yang diperoleh rumah tangga petani pada kegiatan luar usahatani sendiri dan luar usahatani adalah sebesar Rp 21.692.875 per tahun. Jumlah pendapatan ini diperoleh dari semua anggota rumah tangga (bapak dan anak) yang melakukan kegiatan usaha dari luar usahatani sendiri dan luar usahatani (non farm). Untuk lebih jelasnya dapat dilihat pada Tabel 7.

Tabel 7. Rata-rata Pendapatan yang Diterima Rumah Tangga Petani yang Bersumber dari Luar Usahatani

\begin{tabular}{|c|l|c|r|}
\hline No & \multicolumn{1}{|c|}{ Jenis Pekerjaan } & Jumlah (Orang) & $\begin{array}{r}\text { Pendapatan Riil } \\
\text { (Rp/bln) }\end{array}$ \\
\hline 1 & Buruh & 8 & 2.131 .000 \\
2 & Supir & 1 & 6.083 .000 \\
3 & Dagang & 2 & 13.607 .000 \\
4 & Kariawan Toko & 1 & 1.500 .000 \\
5 & Guru Honorer & 1 & 1.635 .000 \\
6 & Pengebor sumur & 3 & 3.573 .000 \\
7 & Wiraswasta & 3.917 .000 \\
\hline
\end{tabular}


Sumber: Data Primer Diolah

\section{Kontribusi Pendapatan Ibu Rumah Tangga dari Berbagai Kegiatan Produktif}

Besar kecilnya pendapatan yang diterima ibu rumah tangga pada akhirnya akan berpengaruh terhadap pendapatan total rumah tangga. Rata-rata pendapatan rumah tangga petani dan kontribusi ibu rumah tangga dari berbagai sumber pendapatan dapat dilihat pada Tabel 8 .

Tabel 8. Rata-rata Pendapatan Rumah Tangga Petani dan Kontribusi Ibu Rumah Tangga dari Berbagai Sumber Pendapatan per tahun

\begin{tabular}{|c|c|r|}
\hline \multirow{2}{*}{ No } & \multicolumn{1}{|c|}{ Sumber Pendapatan } & $\begin{array}{r}\text { Jumlah Pendapatan } \\
\text { (Rp) }\end{array}$ \\
\hline 1 & Pendapatan perempuan tani : & 2.033 .575 \\
& a. Pertanian/Usahatani Sendiri (20 orang) & 36.658 .909 \\
& b. Perdagangan (11 orang) & 9.637 .447 \\
& c. Pengolahan VCO (9 orang) & 15.600 .000 \\
2 & d. Jasa (3 orang) & 14.436 .413 \\
3 & Pendapatan perempuan tani dari kegiatan produktif & 3.484 .810 \\
. & Pendapatan bapak & - \\
& a. usahatani sendiri (21 orang) & 48.768 .461 \\
4 & b. Luar usatani sendiri & - \\
& Pendapatan anggota rumah tangga lainnya & - \\
& a. $\quad$ usahatani sendiri & 34.745 .000 \\
5 & b. Luar usatani sendiri & Luar Usahatani (5 orang) \\
\hline
\end{tabular}

Sumber: Data Primer Diolah

Dari Tabel 8 dapat diketahui bahwa rata-rata pendapatan yang diperoleh rumah tangga petani dari berbagai sumber pendapatan adalah sebesar Rp. 36.458 .81 per tahun. Sedangkan Rata-rata pendapatan perempuan tani per tahunnya mencapai 14.436.413, pada tabel tersebut juga dapat dilihat bahwa anggota keluarga lain (anak) juga memberi kontribusi bagi pendapatan rumahtangga meskipun yang berkontribusi hanya 5 orang,

\section{Kontribusi Pendapoatan Perempuan Tani terhadap Pendapatan Rumahtangga}

Rata-rata kontribusi pendapatan perempuan tani terhadap pendapatan rumahtangga petani mencapai $52,85 \%$, dengan kisaran $0,7 \%-100 \%$. Terdapat 5 orang perempuan tani yang memiliki kontribusi mencapai $100 \%$, jenis pekerjaan yang dilakukan 2 orang dari usahatani sendiri, 2 orang mengolah VCO dan 1 orang berdagang, dan 3 orang diantaranya masih berusia $31-41$ tahun.

Besaran kontribusi perempuan tani sangat beragam, distribusi responden berdasarkan besaran kontribusi ini dapat dilihat pada Tabel 9. 
Tabel 9. Distribusi Responden berdasarkan Besaran Kontribusi Pendapatan Perempuan tani terhadap Pendapatan Rumahtangga Petani

\begin{tabular}{|c|c|c|c|}
\hline No & Nilai Kontribusi (\%) & Jumlah & Persentase (\%) \\
\hline 1 & $\leq 10$ & 9 & 22,5 \\
2 & $10,1-25$ & 4 & 10,0 \\
3 & $25,1-50$ & 9 & 22,5 \\
4 & $50,1-75$ & 4 & 10,0 \\
5 & $75,1-100$ & 14 & 35,0 \\
\hline
\end{tabular}

Pada Tabel 9 dapat dilihat bahwa perempuan tani yang berkontribusi lebih besar dari 50\% mencapai 45\% (18 responden), ini menunjukkan bahwa peran perempuan tani dalam meningkatkan pendapatan rumahtangga cukup besar, meskipun tingkat pendidikan mereka sebagian besar rendah (tidak tamat SD - tamat SMP) yaitu mencapai $87,5 \%$.

\section{KESIMPULAN DAN SARAN}

\section{Kesimpulan}

1. Kegiatan produktif perempuan tani meliputi : kegiatan pada usahatani sendiri sebanyak 20 orang $(47,5 \%)$, dengan rata-rata pendapatan per bulan sebesar Rp 169.465; berdagang sebanyak 11 orang ( $27,5 \%$ ) dengan rata-rata pendapatan Rp 3.609.500 per bulan; pengolahan VCO sebanyak 9 orang $(22,5 \%)$ dengan ratarata pendapatan $\mathrm{Rp} 803.121$ per bulan; dan jasa 3 orang $(7,5 \%)$, dengan rata-rata pedapatan per bulan Rp 1.600.000.

2. Kontribusi pendapatan perempuan tani terhadap pendapatan rumah tangga petani rata-rata sebesar $52,85 \%, 45 \%$ perempuan tani berkontribusi lebih besar dari $50 \%$.

\section{Saran}

Untuk meningkatkan perekonomian daerah salah satu yang harus dilakukan pemerintah yaitu dengan cara memberi pelatihan khusus dan membentuk kelompokkelompok untuk ibu-ibu yang ingin ikut serta dalam meningkatkan perekonomian keluarganya dalam hal keterampilan dan kemampuan untuk berbagai kegiatan produktif, sehingga ibu-ibu tidak hanya ikut ke sawah bersama suami namum juga akan memiliki penghasilan dari kegiatan lainnya.

\section{DAFTAR PUSTAKA}

Amrullah. 2008. Kontribusi Wanita Pedagang Buah Terhadap Pendapatan Rumahtangga di Kecamatan Narmada Kabupaten Lombok Barat. Fakultas Pertanian. Universitas Mataram. Mataram.

Fujiati, D,.2014. Relasi Gender dalam Institusi Keluarga Dalam Pandangan Teori Sosial dan Feminis. Muwazah. Yogyakarta.

Wiliam-de Vries, Dede. 2006. Gender Bukan Tabu: Catatan Perjalanan Fasilitas Kelompok Perempuan di Jambi.Center for International Forestry Research (CIFOR).Bogor (E-book https://books.google.co.id/books/about/Gender_ 
bukan_tabu_catatan_perjalanan_fas.html?

$\mathrm{id}=$ YO4WDVWmMuUC\&redir_esc=y). 